\title{
Cover Story
}

\section{Overview of Monitoring Techniques for Evaluating Water Quality at Potable Reuse Treatment Facilities}

NEEDLESS TO SAY, THE SAFETY

OF TREATED WATER FOR POTABLE REUSE MUST BE

DEFINITIVELY ENSURED.

NUMEROUS METHODS ARE

AVAILABLE FOR ASSESSING

WATER QUALITY; IT'S IMPORTANT TO UNDERSTAND

THEIR CHALLENGES AND LIMITATIONS.
I

ncreased demand on water supplies, associated with population growth and changes in climatic patterns, has made it necessary for many utilities to consider augmenting their current drinking water sources with recycled water-i.e., potable reuse. For regions with imminent water supply shortages due to uncharacteristically long periods of drought or significant population shifts, the primary options for increasing water supply are water importation, saltwater desalination, and water reuse (Snyder 2014). Water reuse may include a combination of potable and nonpotable uses to increase water supply resiliency. Nonpotable reuse is water not intended for direct human consumption, such as irrigation or coolingtower water. Potable reuse involves integrating highly treated municipal wastewater directly into drinking water systems, which may or may not include retention in an engineered storage buffer before its introduction, such as direct versus indirect potable reuse.

\section{CURRENT EXTENT OF POTABLE REUSE}

In the United States, approximately $7-8 \%$ of the 32 bil gal of treated municipal wastewater effluent is recycled (USEPA 2012). Potable reuse was 
implemented in the United States more than five decades ago, with the first planned project at the Los Angeles County Sanitation District's Montebello Forebay aquiferrecharge spreading grounds in 1962 (USEPA 2012). The US Environmental Protection Agency (USEPA) developed the first national policy statement on water reuse in 1972 (USEPA 1972), and the National Research Council developed the first set of water quality criteria for reuse in 1982 (NRC 1982).

USEPA developed the Guidelines for Water Reuse in 1980, which went through three revisions (USEPA 2012, 2004, 1992, 1980). The agency recently published a supplement titled 2017 Potable Reuse Compendium (USEPA 2017), appending the Guidelines for Water Reuse to include more details for potable reuse. While there are no federal regulations specific to potable reuse in the United States, the Safe Drinking Water Act (SDWA) and the Clean Water Act (CWA) provide the statutory requirements for water quality that apply to potable reuse scenarios. Wastewater effluent must meet requirements set forth by the CWA and the National Pollutant Discharge Elimination System. Subsequently, advanced treated water must meet the requirements of the SDWA and National Primary Drinking Water Regulation (NPDWR) maximum contaminant levels (MCLs) and abide by nonregulatory water quality standards for aesthetics in the National Secondary Drinking Water Regulation MCLs.

Specific regulations, policies, provisions, and/or guidance for potable reuse have been developed in 15 states: Arizona, California, Florida, Hawaii, Idaho, Massachusetts, Nevada, New Mexico, North Carolina, Oklahoma, Oregon, Pennsylvania, Texas, Virginia, and Washington (USEPA 2017). In California, the State Water Resources Control Board developed a report for the legislature on the Feasibility of Developing Uniform Water Recycling Criteria for
Direct Potable Reuse in 2016 (SWRCB 2016). At least 25 potable reuse projects have been implemented in nine states, and several more are or have been under study.

While several recent pilot and demonstration-scale studies have been conducted, two notable full-scale potable reuse facilities have provided water directly into the distribution system: Big Spring Colorado River Municipal Water District (1.6 mgd) in 2013 and Wichita Falls (5 mgd) in 2014, both of which are in Texas. There are two additional potable reuse facilities in the process of construction and permitting: Village of Cloudcroft, N.M., and the El Paso Advanced Water Purification Facility in Texas. Figure 1 shows a map of potable reuse projects in the United States.

From a global perspective, potable reuse is expanding and will continue to grow as a means to meet drinking water supply needs in the decades to come (Khan 2013). Probably the most well-known international project is the Goreangab Water Reclamation Plant in Windhoek, Namibia, which began in 1969 and was expanded in 2002 to produce $5.5 \mathrm{mgd}$ of potable water (USEPA 2012). This facility supplies approximately $50 \%$ of the city's potable water demand (NRC 2012). Australia was the first country to develop federal potable reuse guidelines when Phase 2 (which included Augmentation of Drinking Water Supplies) of the Australian Guidelines for Water Recycling was released in 2008 (EPHC et al. 2008). Singapore's NEWater facilities can provide up to $40 \%$ of the nation's water supply needs with water that meets or exceeds USEPA's drinking water standards and the World Health Organization's guidelines (USEPA 2017, 2012; WHO 2017).

\section{CHALLENGES IN DEFINING MONITORING}

Potable reuse requires careful monitoring of pathogens and chemical contaminants because of their potentially higher concentrations in the source water. Ultimately, monitoring systems need to be accurate, technically accessible, and cost-effective to be successful (Mosher et al. 2016).

There has been great interest in further developing and adopting new monitoring techniques to incorporate indicator and surrogate

\section{FIGURE 1 Potable reuse projects in the United States}

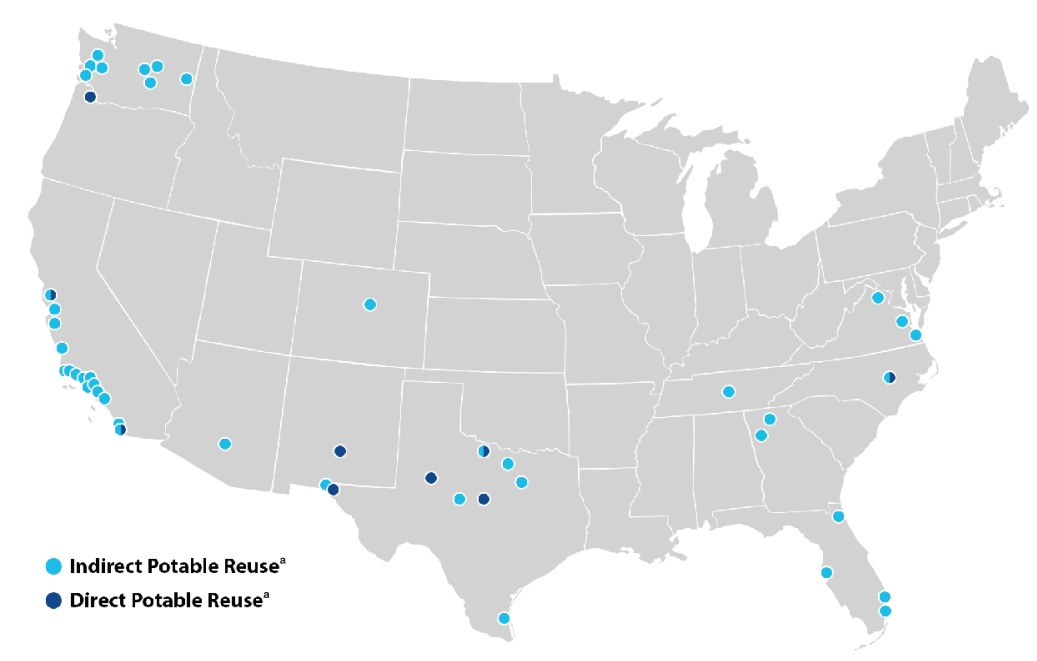

aincludes pilots, studies, and prospective projects

Source: Rock et al. 2019, as adapted from USEPA 2017. (C) Water Research Foundation. Used with permission. 
compounds, optical sensors and biosensors, and bioassays. An indicator compound is an individual chemical or microorganism occurring at a measurable level that represents certain physiochemical and biodegradable characteristics of either a group of trace chemical constituents or microorganisms of interest (NRC 2012, USEPA 2012, Drewes et al. 2008, WHO 2001). For example, Escherichia coli (E. coli) or coliphages are used as microbial indicators for evaluating disinfection log-reduction credits. A surrogate parameter is a measurable change of a bulk parameter that can assess the performance of a treatment barrier and can be consistently monitored (NRC 2012, USEPA 2012). Turbidity is often monitored for overall treatment performance and for demonstrating pathogen removal across filtration.

Indicators and surrogates must be selected on the basis of knowledge of suspected target contaminants. These must also be present at sufficiently high concentrations that are above their relative detection limits (Crook et al. 2013). Drewes et al. (2008) performed an extensive evaluation of indicator and surrogate compounds for wastewater and water reclamation. They noted that a suite of indicator compounds and surrogates should be used to encompass a variety of physical-chemical properties and behaviors to help determine the removal efficacy for specific treatment barriers in instances where actual concentrations cannot be measured.

In the United States, use or adoption of a monitoring tool or technique must demonstrate pathogen log-reduction credits required by state regulatory agencies. The riskbased approach used by the SDWA Surface Water Treatment Rule can apply to potable reuse scenarios to demonstrate that the appropriate level of protection of human health has been achieved (Mosher et al. 2016). Monitoring schemes must also incorporate verification of water quality at critical control points (Walker et al. 2016, Halliwell et al.

FIGURE 2 Grab samples at advanced treatment critical control points in a potable reuse facility

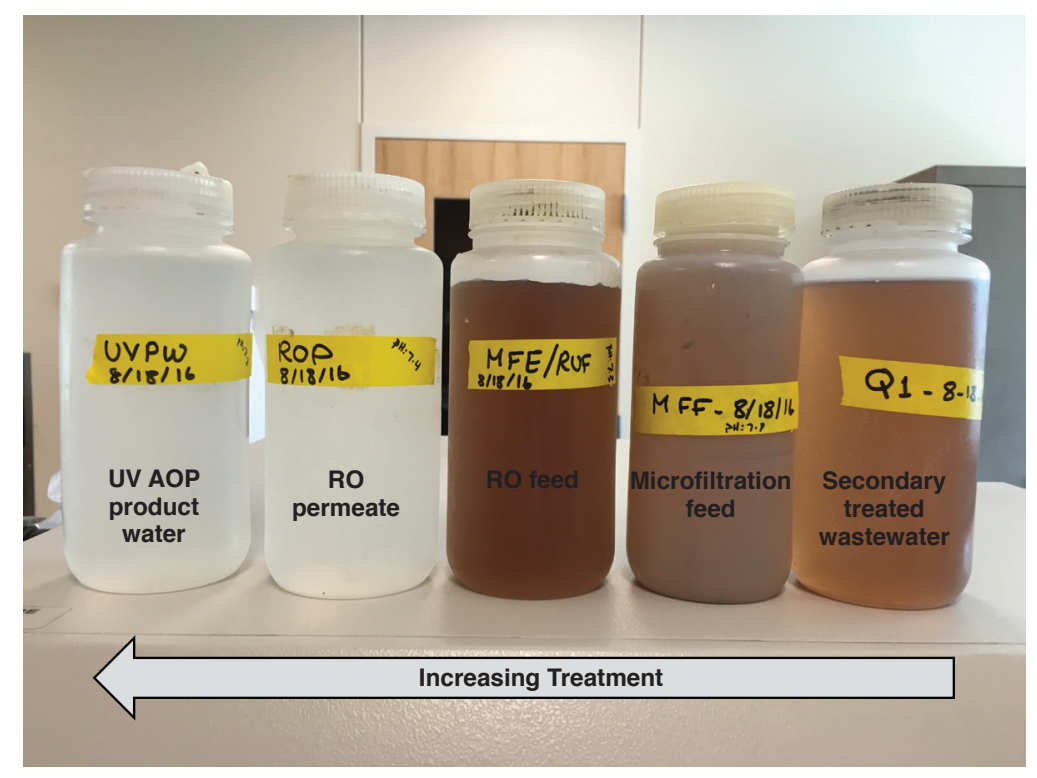

Source: University of Arizona. Printed with permission.

AOP-advanced oxidation process, $\mathrm{RO}$-reverse osmosis, UV-ultraviolet
2014, Salveson et al. 2014). Figure 2 shows examples of grab samples at critical control points through an advanced treatment scheme at a potable reuse facility. For direct potable reuse, the absence of an environmental buffer reduces failure response times, so the overall treatment process and associated monitoring program must be resilient enough to respond quickly and effectively if off-specification water is encountered (Pepper \& Snyder 2016, Pecson et al. 2015).

\section{MONITORING PATHOGENIC MICROORGANISMS AND VIRUSES}

Pathogens are characterized into three groups: bacteria, protozoa, and viruses. In general, bacteria can be destroyed, whereas protozoa and viruses are typically removed or inactivated. Virus removal is particularly important because of the occurrence of viruses in municipal wastewater and acute health impacts (Khan 2013).

Bacteria. In general, bacteria range in size from 0.2 to $10 \mu \mathrm{m}$ in length, so they are large enough to be effectively removed via filtration, while they are also susceptible to chemical or ultraviolet (UV) disinfection. Enteric pathogenic bacteria tend to be present in lower concentrations in wastewater than indicator species. E. coli, Enterococcus spp., and fecal coliforms are often used as indicators of fecal bacteria. E. coli and enterococci are recommended by USEPA as an indicator of fecal pollution in freshwater recreational waters because levels of these organisms were shown to be more accurate than fecal coliforms at predicting gastrointestinal illness (USEPA 2012, 2004). Fecal coliforms may also be selected for monitoring simply because many utilities already use fecal coliforms for routine testing. Table 1 shows typical indicator organisms for monitoring pathogenic bacteria, protozoa and helminths, and viruses (also see the photograph on page 15). 
TABLE 1 Example pathogens, indicator organisms, and detection methods

\begin{tabular}{|c|c|c|c|}
\hline Group & Pathogens & Indicators & Detection Methods \\
\hline Bacteria & $\begin{array}{l}\text { Aeromonas hydrophila, atypical mycobacteria, } \\
\text { Campylobacter, Legionella, Pseudomonas, } \\
\text { Salmonella, Shigella, Staphylococcus, Vibrio } \\
\text { cholera, Yersina }\end{array}$ & $\begin{array}{l}\text { Total coliforms, E. coli, } \\
\text { enterococci, pseudomonas }\end{array}$ & $\begin{array}{l}\text { Cell culture: IDEXX Colilert } \\
\text { (see the photograph on this } \\
\text { page), Enterolert, Pseudolert } \\
\text { Biological molecules: ATP }\end{array}$ \\
\hline Protozoa & $\begin{array}{l}\text { Giardia lamblia, Cryptosporidium parvum, } \\
\text { Entamoeba, Cyclospora, Isospora, } \\
\text { Microsporidia, Toxoplasma }\end{array}$ & $\begin{array}{c}\text { Clostridium perfringens or } \\
\text { Bacillius subtilis spores }\end{array}$ & $\begin{array}{l}\text { Cell culture such as USEPA } \\
\text { Method } 1623 \\
\text { Direct count }\end{array}$ \\
\hline Helminths & $\begin{array}{l}\text { Ascaris, Ancylostoma, Necator, Ancylostoma, } \\
\text { Strongyloides, Trichuris, Taenia, Entrobius, } \\
\text { Echinococcus }\end{array}$ & $\begin{array}{c}\text { Clostridium perfringens or } \\
\text { Bacillius subtilis spores }\end{array}$ & $\begin{array}{l}\text { Cell culture } \\
\text { Direct count }\end{array}$ \\
\hline Viruses & $\begin{array}{l}\text { Adenovirus, astrovirus, calciciviruses, } \\
\text { coronavirus, enteroviruses, hepatitis, } \\
\text { parvovirus, picornaviruses, rotavirus }\end{array}$ & $\begin{array}{l}\text { Somatic coliphage, male- } \\
\text { specific F+ RNA phage, aichi } \\
\text { virus, calicivirus, pepper } \\
\text { mild mottle virus }\end{array}$ & $\begin{array}{l}\text { Molecular methods such as qPCR, } \\
\text { RT-qPCR, } 16 \mathrm{~S} \text { rRNA sequencing } \\
\text { Virus cell culture such as USEPA } \\
\text { Method } 1615\end{array}$ \\
\hline
\end{tabular}

Adapted from Mosher et al. 2016

ATP—adenosine triphosphate, E. coli-Escherichia coli, qPCR—quantitative polymerase chain reaction, RNA—ribonucleic acid, RT—reverse transcription, USEPA-US Environmental Protection Agency

Protozoa and helminths. Most protozoan spores, cysts, oocysts, and eggs range in size from $1 \mu \mathrm{m}$ to more than $60 \mu \mathrm{m}$ and are thus substantially larger than most bacteria. Protozoa and helminths can be eliminated from wastewater using either a physical removal or an inactivation process, such as ozone oxidation or UV disinfection (Khan 2013). Clostridium perfringens has been used as an indicator for protozoa such as Giardia lamblia and Cryptosporidium parvum. Additionally, because of C. perfringens' ability to form spores, this bacterium can be used as an indicator of pathogenic sporeforming protozoa.

The methods to detect Giardia and Cryptosporidium are intensive, relying heavily on laboratory sample preparation and technician skill, whereas the detection method for C. perfringens is straightforward (though not USEPA approved) and can distinguish between viable and nonviable spores (Mosher et al. 2016, USEPA 2012). In Europe since the 1960s, C. perfringens has been used as an indicator of fecal contamination in water (NRC 2004). North Carolina uses C. perfringens as an indicator in its water reuse regulations; to date it is the only state in the country that uses C. perfringens as a protozoan indicator for water reuse monitoring. Florida uses Cryptosporidium.

Viruses. Ranging in size from 0.01 to $0.3 \mu \mathrm{m}$, viruses are far smaller than bacteria or parasites. Enteric viruses replicate in the intestinal tracts of their hosts and are found in the fecal matter of those infected. Monitoring for pathogenic viruses is challenging because not only are

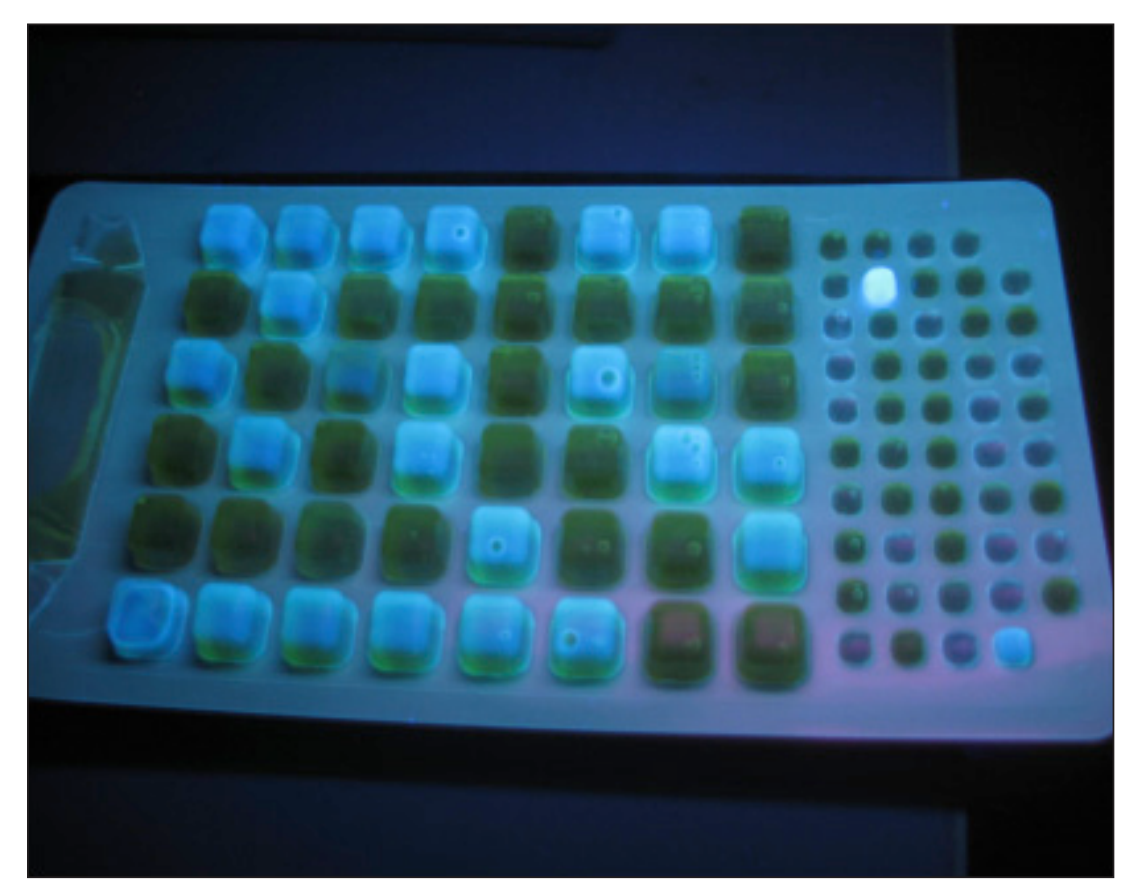

Methods such as the IDEXX Colilert microbiological assay can be used to detect bacterial pathogens including total coliforms and Escherichia coli. Source: University of Arizona. Printed with permission.

they notoriously difficult to detect, there are more than 100 pathogenic enteric viruses and viruses (USEPA 2017). However, viruses cannot replicate outside of their host and thus cannot multiply during wastewater or reclaimed water treatment. Virus removal and inactivation is complex and species-specific, yet it can be achieved through coagulation/ 
TABLE 2 Bacteriophages as indicators of pathogenic enteric viruses

\begin{tabular}{|c|c|c|c|}
\hline Description & Examples & Wastewater Prevalence & Advantages and Disadvantages \\
\hline \multicolumn{4}{|c|}{ Somatic Coliphage } \\
\hline $\begin{array}{l}\text { Infect host cells } \\
\text { (E. coli and other } \\
\text { Enterobacteriaceae) } \\
\text { by attaching to } \\
\text { receptors located in } \\
\text { the bacterial cell wall }\end{array}$ & $\begin{array}{l}\text { T-4, T-7, } \\
\Phi X 174 \\
\text { PRD-1 }\end{array}$ & $\begin{array}{l}\text { Most abundant bacteriophage } \\
\text { group } \\
\text { Low concentrations in human } \\
\text { feces }(<10 / \mathrm{g})^{\mathrm{a}} \\
\text { High concentrations in untreated } \\
\text { wastewater }\left(1 \times 10^{4} \text { to } 1 \times 10^{5}\right. \\
\text { particles/g) and animal feces }{ }^{\mathrm{a}}\end{array}$ & $\begin{array}{l}\text { Easily detectable and proven useful as viral surrogates in bench, } \\
\text { pilot, and validation testingb,c } \\
\text { Not uniquely of human origin }{ }^{d} \\
\text { Can multiply in water, e though may be negligible } \\
\text { Not predictive of pathogens in groundwaterg }\end{array}$ \\
\hline \multicolumn{4}{|c|}{ Male-specific F+ RNA phage } \\
\hline $\begin{array}{l}\text { Attach to fertility } \\
\text { fimbriae (F-pili) } \\
\text { produced by male } \\
\text { bacterial cells, } \\
\text { including } E \text {. coli and } \\
\text { many other hostsh }\end{array}$ & MS2 and $\mathrm{f} 2$ & $\begin{array}{l}\text { Second most abundant } \\
\text { bacteriophage group }{ }^{\mathrm{i}, \mathrm{j}} \\
\text { Low concentrations in human } \\
\text { and animal feces }\left(1 \times 10^{3} / \mathrm{g}\right) \\
\text { Frequent detection in wastewater } \\
\quad\left(1 \times 10^{3} \text { to } 1 \times 10^{4} / \mathrm{mL}\right)^{\mathrm{a}, \mathrm{e}}\end{array}$ & $\begin{array}{l}\text { Similar in morphology and physiochemistry to pathogenic } \\
\text { human enteric viruses }{ }^{\mathrm{a}, \mathrm{b}, \mathrm{k}} \\
\text { Conservative indicator of persistence; less susceptible to } \\
\text { chlorine disinfection }{ }^{1, \mathrm{~m}} \\
\text { Can distinguish human from animal fecal sources } \mathrm{d}, \mathrm{n}, \mathrm{o} \\
\text { Persistence in surface waters is low in warm climates }{ }^{\mathrm{i}, \mathrm{j}} \\
\text { Degree of replication in the environment is unknown } \\
\text { keg }\end{array}$ \\
\hline \multicolumn{4}{|c|}{ Bacteroides fragilis phages } \\
\hline $\begin{array}{l}\text { Infect Bacteroides } \\
\text { fragilis, an anaerobic } \\
\text { bacterium abundant } \\
\text { in human feces }\end{array}$ & $\begin{array}{l}\text { B40-8 and } \\
\text { B56-3 }\end{array}$ & $\begin{array}{l}\text { Third most abundant } \\
\text { bacteriophage group } \\
\text { High concentrations in human } \\
\text { feces }\left(1 \times 10^{8} / \mathrm{g}\right) \text { and } \\
\text { environmental samples with } \\
\text { human fecal pollution }\end{array}$ & $\begin{array}{l}\text { Unable to replicate in the environmentq } \\
\text { Can distinguish human from animal fecal sourcesc,r } \\
\text { Similar environmental persistence as some enteric viruses } \\
\text { Tedious cultivation since host is a strict anaerobe } \\
\text { Different hosts needed for different regions }{ }^{c}\end{array}$ \\
\hline
\end{tabular}

Source: Rock et al. 2016. Reprinted with permission. @ Water Research Foundation.

E. coli-Escherichia coli, RNA-ribonucleic acid

aHavelaar et al. 1986

bWHO 2004

cLucena \& Jofre 2010

dHsu et al. 1996

eGerba 2006

fJofre 2009

gPayment \& Locas 2011

hHavelaar 1987

iChung \& Sobsey 1993

iMocé-Llivina et al. 2005

kJofre et al. 2011

${ }^{1}$ Havelaar et al. 1993

mLove \& Sobsey 2007

nHsu et al. 1995

oScott et al. 2002

pHavelaar et al. 1990

qTartera et al. 1989

rEbdon et al. 2007

sTartera \& Jofre 1987

flocculation/sedimentation, chemical disinfection, UV disinfection, ozone oxidation, and media or membrane filtration (Myrmel et al. 2006).

Because enteric viruses are difficult to detect, indicator viruses-most often bacteriophages (also known as phages)—are used. Bacteriophages are viruses that infect bacteria; they do not infect humans. Three main groups of bacteriophages are frequently used as surrogates for pathogenic waterborne viruses: somatic coliphages, male-specific or F+ ribonucleic acid (RNA) phages, and Bacteroides fragilis phages (Lucena \& Jofre 2010, WHO 2004, IAWPRC Study Group 1991). There is a lack of consensus about which group serves as the best indicator of enteric viruses. Advantages and disadvantages of each category are presented in Table 2.

Pathogen detection methods. The best methods for monitoring pathogens are rapid, highly sensitive, selective, and can distinguish between viable and nonviable organisms. No single method achieves all of these goals, so a suite of methods is recommended (Mosher et al. 2016). Indicator organisms must be present in sufficient concentrations to assess removal and must either strongly correlate to or be conservative with respect to the pathogen of interest.
Samples are typically concentrated to improve sensitivity using membrane filters, magnetic beads, or microfluidic devices that discriminate particles on the basis of charge or size. Molecular biological methods are highly sensitive-i.e., able to detect single copies of a genome. One concern with molecular methods is that they do not distinguish viable from nonviable cells or infectivity of viruses. Immunological methods tend to be more rapid than molecular biology methods because they don't require as much sample pretreatment, but they are less sensitive (Connelly \& Baeumner 2012). Table 3 highlights common detection 
TABLE 3 Common methods used to detect pathogenic microorganisms and viruses

\begin{tabular}{|c|c|}
\hline Method & Description \\
\hline Cell-culture-based methods & $\begin{array}{l}\text { Methods for bacteria involve plating on agar media. Quantities can be estimated by conducting } \\
\text { multiple dilutions and counting bacterial colonies after incubation. For viruses, the plating media has } \\
\text { a permissive cell line. The death of the cells indicates the presence of the infectious virus. The } \\
\text { photograph on page } 18 \text { shows colonies of Clostridium sp. cultivation on agar media. }\end{array}$ \\
\hline Biological molecule assays & $\begin{array}{l}\text { Bioenergy molecules such as adenosine triphosphate (ATP) or nicotinamide adenine dinucleotide } \\
\text { phosphate }\left(\mathrm{NADP}^{+}\right) \text {are present in all living organisms. ATP and NADP+ are not present in viruses. } \\
\text { Hydrolase enzymes, which represent a large class of microbiological household enzymes, may also be } \\
\text { used for quantifying biomass. }\end{array}$ \\
\hline Immunological assays & $\begin{array}{l}\text { These assays are highly selective but not highly sensitive. Examples include the enzyme linked } \\
\text { immunosorbent assay and serum neutralization tests. }\end{array}$ \\
\hline $\begin{array}{l}\text { Polymerase chain reaction (PCR), } \\
\text { quantitative PCR (qPCR) }\end{array}$ & $\begin{array}{l}\text { PCR allows for the identification of the deoxyribonucleic acid (DNA) or ribonucleic acid (RNA) of } \\
\text { pathogens or indicators present in a water sample. qPCR allows for the DNA or RNA to be quantified } \\
\text { and is relatively rapid (less than } 8 \text { hours). }\end{array}$ \\
\hline $\begin{array}{l}\text { Nucleic acid sequence-based } \\
\text { amplification (NASBA) }\end{array}$ & $\begin{array}{l}\text { NASBA uses isothermic conditions for DNA or RNA amplification (rather than the temperature cycles } \\
\text { used in PCR and qPCR), and therefore may be somewhat faster than PCR-based methods. }\end{array}$ \\
\hline Droplet digital PCR & $\begin{array}{l}\text { Samples are partitioned into thousands to millions of nanoliter or picolitre volumes inside small } \\
\text { chambers on a chip (i.e., chamber digital PCR) or within a water-in-oil droplet (i.e., droplet digital } \\
\text { PCR) before PCR amplification. The frequency of positive partitions is used with Poisson statistics to } \\
\text { estimate the number of target copies in the original sample. }\end{array}$ \\
\hline Pyrosequencing & $\begin{array}{l}\text { This technology starts with a single-stranded PCR product to which a primer is added to initiate a } \\
\text { DNA-sequencing reaction. }\end{array}$ \\
\hline
\end{tabular}

\section{Physical Detection}

\begin{tabular}{|c|c|}
\hline Turbidity & $\begin{array}{l}\text { Higher-turbidity water may have a higher likelihood of having pathogens present, though correlations } \\
\text { are not straightforward or ensured. }\end{array}$ \\
\hline Light scattering & $\begin{array}{l}\text { Suspended particles can be detected because of their ability to scatter light in water. Multi-angle light- } \\
\text { scattering technology uses lasers and light-scattering detectors to determine the shape and size of } \\
\text { particles. }\end{array}$ \\
\hline Microscopic identification & $\begin{array}{l}\text { An example microscopic identification method is USEPA method } 1623 \text { for detecting Cryptosporidium } \\
\text { parvum and Giardia lamblia. A sample is filtered, and then the oocysts and cysts are separated from the } \\
\text { material captured using magnetic beads conjugated to anti-C. parvum and anti-G. lamblia antibodies, } \\
\text { then eluted, stained, and counted with differential interference contrast microscopy. BioSentry is } \\
\text { another tool for microscopic identification and can detect between } 10^{2} \text { and } 10^{5} \text { spores } / \mathrm{mL} \text {. }\end{array}$ \\
\hline Spectroscopy & $\begin{array}{l}\text { Raman spectroscopy involves ultraviolet through visible to near infrared light excitation. Surface- } \\
\text { enhanced Raman spectroscopy (SERS) can identify specific microorganisms. }{ }^{\text {a }} \text { Optical tweezers can } \\
\text { isolate bacteria, allowing discrimination between different strains of bacteria. }{ }^{\text {b Fourier transform }} \\
\text { infrared (FTIR) spectroscopy involves the excitation of molecules by infrared light and the unique } \\
\text { signature spectra is measured. Matrix-assisted laser desorption/ionization time-of-flight mass } \\
\text { spectrometry detects the mass to charge ratio of particles to provide a "fingerprint" of specific } \\
\text { microorganisms.c }\end{array}$ \\
\hline Flow cytometry (FC) & $\begin{array}{l}\text { FC can be combined with the use of nucleic acid probes or fluorescent antibodies to rapidly identify } \\
\text { and quantify specific microorganisms. Researchers have presented methods to identify pathogenic } E \text {. } \\
\text { coli O157:H7, C. parvum, and nonpathogenic E. coli in water. } \text { d-f Sensitivity has improved through the }_{\text {amplification of viral signals as a result of the use of a novel nucleic acid dye, SYBR-Gold. These recent }} \\
\text { advancements make near-real-time measurements for total bacteria and viruses in water a practical } \\
\text { possibility. }\end{array}$ \\
\hline
\end{tabular}

E. coli-Escherichia coli, USEPA-US Environmental Protection Agency

aporter et al. 2006

bYu et al. 2004

cWelker and Moore 2011

dDeCory et al. 2005

eWolter et al. 2008

fWare et al. 2003

methods for microbial and viral pathogens (also see the photograph on page 18).

Water quality parameters examined in wastewater and drinking water also apply to potable reuse. In the United States, finished water quality must meet all NPDWR MCLs specified in the SDWA and should maintain water quality that meets the guidelines set forth in the National Secondary Drinking Water Regulations for aesthetics. Generally, chemicals are present at low-enough concentrations in treated municipal wastewater to mitigate acute risk. Potable reuse facilities should incorporate monitoring of unregulated compounds, particularly those listed in the fourth Unregulated Contaminant Monitoring Rule, because of the increased likelihood that these compounds will be present during advanced treatment.

Surrogates. Bulk surrogate chemical parameters provide information on the general functionality of treatment 


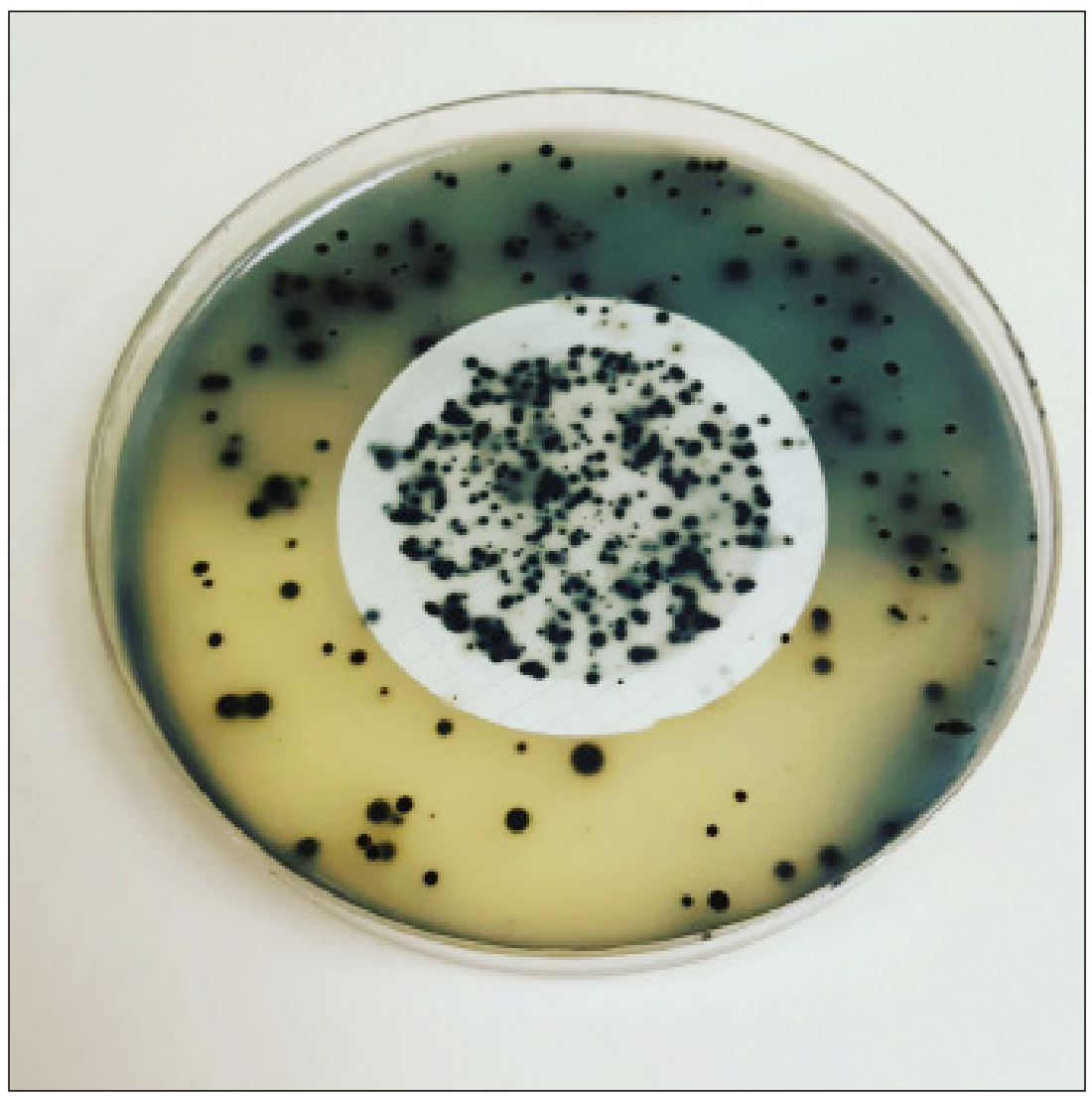

Cell-culture-based methods can be used to detect bacteria, such as colonies of Clostridium sp. being cultivated on agar media. Source: University of Arizona. Printed with permission.

processes and their ongoing performance for removing pathogens and other chemicals (Crook et al. 2013). Though each unit treatment process has its own bulk surrogate parameters that lend information on treatment performance, some are applicable across multiple methods. Such surrogates include conductivity, boron, calcium, magnesium, UV absorbance, total organic carbon continue to be the most reliable methods for measuring changes in drinking water quality in real time (Storey et al. 2010).

For potable reuse scenarios that include an environmental buffer, a wastewater tracer test can assess dilution and contaminant degradation in receiving water bodies. Wastewater tracers must be recalcitrant and not easily removed during treatment. For example, primidone and carbamazepine are not easily biodegraded and exhibit poor removal $(<25 \%)$ during soil-aquifer treatment (SAT) (Drewes et al. 2008). These compounds can be used to track wastewater contributions to groundwater during SAT. Artificial sweeteners, such as sucralose and acesulfame-K, are also relatively nondegradable in nature yet abundantly present at levels above their detection limits, and they serve as conservative tracers for the presence of wastewater in surface water and groundwater (Anderson et al. 2010). Sucralose is useful for evaluating the removal of water-soluble, uncharged chemicals with moderate molecular weights (Crook et al. 2013).

Trace chemical constituents. Trace chemical constituents encompass an array of compounds, including industrial, manufacturing, and consumer products, as well as personal care products and pharmaceuticals; example constituents are described in Table 5. Their concentrations in raw, secondary, and tertiary treated

TABLE 4 Surrogate parameters for monitoring in potable reuse

\begin{tabular}{l|l}
\hline \multicolumn{1}{c|}{ Category } & \multicolumn{1}{c}{ Parameter } \\
\hline General conditions & Alkalinity, color, conductivity, hardness, $\mathrm{pH}$, temperature, total dissolved solids \\
\hline Treatment performance & Biological oxidant demand, chemical oxidant demand, dissolved oxygen, turbidity \\
\hline Disinfection performance & Disinfectant residual, $C \times T, E$. coli, fecal coliform, turbidity \\
\hline Nutrients & Ammonia, nitrate, nitrite, orthophosphate, total Kjeldahl nitrogen, total phosphorus \\
\hline Other & $\begin{array}{l}\text { Dissolved organic carbon, fluorescence, specific ultraviolet absorption, total suspended solids, total organic } \\
\text { carbon, ultraviolet absorption }\end{array}$ \\
\hline
\end{tabular}

Modified from Rock et al. 2016. Reprinted with permission. (C) Water Research Foundation.

$C \times T$-concentration times time, E. coli-Escherichia coli 
TABLE 5 Categories and example compounds of trace chemical constituents

\begin{tabular}{|c|c|}
\hline Category & Example Compounds \\
\hline \multicolumn{2}{|r|}{ Industrial, Manufacturing, and Consumer Products } \\
\hline Flame retardants & Tris[2-chloroethyl]phosphate (TCEP), hexabromocyclododecane (HBCD) \\
\hline Propellants & Perchlorate \\
\hline Surfactants/nonylphenols & Nonylphenol diethoxylate, nonylphenol monoethoxylate, para-tert-octylphenol, p-nonylphenol \\
\hline Perfluorinated compounds & $\begin{array}{l}\text { Perfluorooctanesulfonic acid (PFOS), perfluorooctanoic acid (PFOA), perfluorononanoic acid (PFNA), } \\
\text { perfluorohexanesulfonic acid (PFHXS), perfluoroheptanoic acid (PFHpA), perfluorobutanesulfonic acid } \\
\text { (PFBS), perfluorobutanoic acid (PFBA) }\end{array}$ \\
\hline $\begin{array}{l}\text { Pesticides, herbicides, and } \\
\text { fungicides }\end{array}$ & $\begin{array}{l}\text { Atrazine, benzo(a)pyrene, metolachlor, simazine, bentazon, 2,4-D, MCPA, pentachlorophenol (PCP), } \\
\text { carbaryl, } N, N \text {-diethyl-meta-toluamide (DEET) }\end{array}$ \\
\hline Volatile organic compounds & $\begin{array}{l}\text { Methyl-tert-butyl-ether (MTBE), m- and p-xylene, o-xylene, 1,2,4-trimethylbenzene, naphthalene, } \\
\text { isopropylbenzene, benzene, ethylbenzene, carbon tetrachloride, toluene, 1,4-dioxane, tert-butyl alcohol, } \\
\text { acetone (2-propanone), tetrachloroethene (PCE), trichloroethene (TCE), 1,1,1,2-tetrachloroethane, } \\
\text { 1,1,2,2-tetrachloroethane (TCA) }\end{array}$ \\
\hline \multicolumn{2}{|r|}{ Pharmaceuticals and Personal Care Products (PPCPs) } \\
\hline Contrast media & Iopromide \\
\hline Food additives & Sucralose, caffeine, acesulfame-K \\
\hline Personal care products & Bisphenol-A (BPA), triclosan, triphenyl phosphate, camphor, anthraquinone, p-Cresol \\
\hline Pharmaceuticals & $\begin{array}{l}\text { Trimethoprim, fluoxetine, carbamazepine, diltiazem, cotinine, acetaminophen, gemfibrozil, ibuprofen, } \\
\text { naproxen, sulfamethoxazole, primidone, atenolol, furosemide, metoprolol, meprobamate, ofloxacin, } \\
\text { valsartan, hydrochlorothiazide, oxycodone, sertraline, verapamil, salicylic acid }\end{array}$ \\
\hline Sterols and hormones & $\begin{array}{l}\text { Coprostanol, cholesterol, } \beta \text {-sitosterol, } \beta \text {-stigmastanol, androstenedione, estrone, } 17 \text { - } \alpha \text {-ethynyl estradiol, } \\
17-\beta \text { estradiol }\end{array}$ \\
\hline
\end{tabular}

wastewater are wide-ranging (Drewes et al. 2008). A survey of 19 drinking water treatments in the United States demonstrated maximum finished-water constituents of emerging concern (CECs) at concentrations below $100 \mathrm{ng} / \mathrm{L}$, except for the flame retardant tris (1-chloro2-propyl) phosphate (commonly known as TCPP), which had a maximum concentration of $510 \mathrm{ng} / \mathrm{L}$ (Snyder et al. 2008).

In California, the Water Quality Control for Recycled Water, also known as the Recycled Water Policy, was adopted by the State Water Board in 2009 and amended in 2013 to include CEC monitoring recommended by its science advisory panel (Anderson et al. 2010). The final list of recommended compounds included 489 CECs (Drewes et al. 2018). Four CEC indicator compounds were recommended for potable reuse monitoring by the 2013 National Water Research Institute panelnamely, cotinine, meprobamate, carbamazepine, and estrone, because of the following characteristics (Crook et al. 2013):

- Cotinine: low molecular weight that is likely charged to some degree at $\mathrm{pH}$ values employed in water treatment

- Meprobamate: low molecular weight with a basic structure similar to alkanes and occurs wastewater and occurs at adequate concentrations

- Estrone: natural steroidal hormone that is present at higher levels than $17 \beta$-estradiol or ethinyl estradiol

Chemical constituent detection methods. As shown in Table 6, different analytical methods are needed to quantify trace chemical constituents

\section{While there are no federal regulations specific to potable reuse in the United States, the Safe Drinking Water Act and the Clean Water Act provide the statutory requirements for water quality that apply to potable reuse scenarios.}

abundantly and in sufficient concentrations

- Carbamazepine: low molecular weight, unique structure, recalcitrant, abundant in because of their diverse physicalchemical properties. Despite considerable progress in detection methods, there are no standard methods for quantification. When interpreting 


\section{TABLE 6 Detection methods for contaminants of emerging concern}

\begin{tabular}{l|l}
\hline \multicolumn{1}{c|}{ Detection Method } & Description \\
\hline $\begin{array}{l}\text { Gas chromatography (GC) and } \\
\text { mass spectrometry (MS) }\end{array}$ & $\begin{array}{l}\text { GC/MS is one of the most widely used combined techniques because of its sensitivity and selectively. } \\
\text { MS measures an analyte dependent on its mass to charge ratio. The compound must be charged } \\
\text { before it enters the machine. GC/MS employs two methods to charge or ionize analyte, electron } \\
\text { ionization (EI) and chemical ionization (CI). EI results in molecular fragmentation, which gives } \\
\text { each compound its own "fingerprint" and allows for individual detection; however, sensitivity is } \\
\text { lost. CI involves ionization of a gas and results in less fragmentation than EI. }\end{array}$ \\
\hline $\begin{array}{l}\text { Liquid chromatography (LC) and } \\
\text { tandem MS }\end{array}$ & $\begin{array}{l}\text { LC/MS differs from GC/MS in that the separation of analytes occurs in the liquid phase. LC/MS uses } \\
\text { three ionization techniques: electrospray ionization (ESI), atmospheric pressure chemical } \\
\text { ionization, and atmospheric pressure photoionization. ESI is the most common technique. }\end{array}$ \\
$\begin{array}{l}\text { Isotope dilution LC and } \\
\text { tandem MS }\end{array}$ & $\begin{array}{l}\text { LC/MS/MS involves solid-phase extraction and LC/MS/MS using ESI in positive and negative modes. } \\
\begin{array}{l}\text { Urobilin (fluorescence detection) } \\
\text { as an indicator of fecal }\end{array}\end{array}$ \\
$\begin{array}{l}\text { Urobilin is a metabolic byproduct of heme metabolism that is excreted through human and animal } \\
\text { feces in water. Urobilin has been shown to be a beneficial biomarker for detection of fecal } \\
\text { contamination. Fluorescence detection of urobilin is achieved when urobilinogen-zinc, a chelation } \\
\text { complex, is excited by blue light and exudes a green fluorescence. }\end{array}$ \\
\hline
\end{tabular}

results, there can be uncertainty when measuring contaminants at very low nanogram-per-liter concentrations (Drewes et al. 2008).

Bioanalytical tools. Through drinking water, human exposure to chemicals does not happen singly but rather occurs as a complex mixture of dissolved chemicals and particulate matter. Often chemical toxicity is nonadditive and may be synergistic or antagonistic. Scientific studies have demonstrated that combinations of chemicals that would not elicit an effect on their own can induce significant toxicity when combined (Margiotta-Casaluci et al. 2013). Conversely, antagonistic effects between suites of chemical constituents may occur. Because of the complex nature of constituents in wastewater, in addition to potential synergistic effects of mixtures of compounds, biological assays that can rapidly and comprehensively screen water for a suite of toxicological end points may be useful. However, biological assays tend to be subjective and thus should be used appropriately.

A comprehensive survey of bioassays indicative of a wide range of responses has been published (Escher et al. 2013). These include assays that were sensitive to induction of specific modes of toxicity, such as mutagenicity and genotoxicity, xenobiotic toxicity, reactive toxicity, cytotoxicity, and endocrine disruption, among other modes of action. The conclusions of the study demonstrated that while there are limitations to bioassay techniques, they are a valid tool for water quality assessment that complement chemical analyses. A recent study incorporating 36 bioassays covering 18 biological endpoints indicated that a suite of bioassays can be useful in characterizing multiple toxicological pathways relevant to human health and can guide decision-making with regard to the treatment processes (Jia et al. 2015). The science advisory panel, which convened in 2018 to evaluate risks from CECs in water treated for reuse, recommended that estrogen receptor alpha and the aryl hydrocarbon receptor bioassays be used to respectively assess estrogenic and dioxin-like biological activities in recycled water (Drewes et al. 2018). However, these technologies are relatively immature and require further development in order to identify, create, and standardize bioanalytical tools.

\section{CONCLUSIONS}

Advanced-treated recycled water can be beneficially reused for a variety of purposes, including augmenting drinking water supplies. Multibarrier approaches, including advanced treatment, have been demonstrated to achieve highquality water, even when the source water is significantly degraded (NRC 2012). However, appropriate monitoring schemes are needed to ensure public health protection. A challenge for potable reuse monitoring is how to effectively characterize pathogens, chemical constituents, and emerging contaminants in advanced treated water in an appropriate time frame.

Water quality monitoring must incorporate conventional monitoring schemes that apply to wastewater and drinking water treatment; it must also incorporate high-frequency indicator and surrogate compounds to assess pathogen and chemical removal efficacy. Complex monitoring programs tracking trace chemical constituents aren't required, but indicator compounds such as sucralose or cotinine can be useful to characterize removal of more recalcitrant compounds. Commonly used bulk indicators, such as turbidity and conductivity, remain useful to assess removal of pathogenic organisms, but they have limitations. Additional characterization of pathogen removal using indicator organisms (e.g., total coliform bacteria, Clostridium perfringens, viral indicators, bacteriophages), incorporating a combination of physical detection, cell culture, and/or molecular biological assays, 
may provide useful information to enhance characterization of water quality and subsequent advanced water treatment.

\section{ACKNOWLEDGMENT}

This work was supported by the Water Research Foundation under Project No. 4508, Assessment of Techniques to Evaluate Water Quality from Direct and Indirect Potable Reuse Facilities.

\section{ABOUT THE AUTHORS}

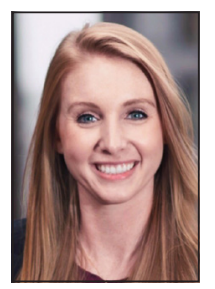

Jillian Vandegrift is

a process design

professional engineer for CDM

Smith in Denver, Colo. She focuses on water reuse,

drinking water, and innovative research and development projects in Colorado and nationwide. Most recently she was a major contributing author to the 2017 Potable Reuse Compendium published by the USEPA as a supplement to the 2012 Guidelines for Water Reuse. Vandegrift was a project engineer on Water Research Foundation Project 4508, Assessment of Techniques to Evaluate and Demonstrate the Safety of Water From Direct Potable Reuse Facilities. In 2016, she was recognized as WateReuse Young Professional of the Year for her efforts in the field thus far in her career. Jennifer Hooper is an environmental engineer at CDM Smith in Bellevue, Wash. Allegra da Silva is an environmental engineer at Brown and Caldwell in Denver. Kati Bell is director of Water Strategy at Brown and Caldwell in Nashville, Tenn. Shane Snyder is a professor in the Department of Chemical and Environmental Engineering at the University of Arizona, Tucson, Ariz. Channah M. Rock (to whom correspondence may be addressed) is associate professor and extension specialist-water quality at the University of Arizona-
Maricopa, 37860 W. Smith-Enke Rd., Maricopa, AZ 85138 USA; channab@cals.arizona.edu.

https://doi.org/10.1002/awwa.1320

\section{REFERENCES}

Anderson, P.; Denslow, N.; Drewes, J.E.; Olivieri, A.; Schlenk, D.; \& Snyder, S., 2010. Monitoring Strategies for Chemicals of Emerging Concern (CECs) in Recycled Water: Recommendations of a Science Advisory Panel. California State Water Resources Control Board, Sacramento, Calif.

Chung, H. \& Sobsey, M.D., 1993. Comparative Survival of Indicator Viruses and Enteric Viruses in Seawater and Sediment. Water Science \& Technology, 27:3-4:425. https://doi.org/10.2166/wst.1993.0385.

Connelly, J.T. \& Baeumner, A.J., 2012. Bio-sensors for the Detection of Waterborne Pathogens. Analytical and Bioanalytical Chemistry, 402:1:117. https:// doi.org/10.1007/s00216-011-5407-3.

Crook, J.; Bull, R.; Collins, H.F.; Cotruvo, J.A.; \& Jakubowski, W., 2013. Examining the Criteria for Direct Potable Reuse, Recommendations of an NWRI Independent Advisory Panel (WRRF 11-02). WateReuse Research Foundation, Alexandria, Va.

DeCory, T.R.; Durst, R.A.; Zimmerman, S.J.; Garringer, L.A.; Paluca, G.; DeCory, H.H.; \& Montagna, R.A., 2005. Development of an Immunomagnetic Bead-Immunoliposome Fluorescence Assay for Rapid Detection of Escherichia coli 0157:H7 in Aqueous Samples and Comparison of the Assay With a Standard Microbiological Method. Applied and Environmental Microbiology, 71:4:1856. https://doi.org/10.1128/AEM.71.4.18561864.2005.

Drewes, J.E.; Anderson, P.; Denslow, N.; Jakubowski, W.; Olivieri, A.; Schlenk, D.; and Snyder, S., 2018. Monitoring Strategies for Constituents of Emerging Concern (CECs) in Recycled Water: Recommendations of a Science Advisory Panel. State Water Resources Control Board, Sacramento, Calif.

Drewes, J.E.; Sedlak, D.; Lim, M.H.; Dickenson, E.; Luna, J.; Snyder, S.; Vanderford, B.; \& Trenholm, B., 2008. Development of Indicators and Surrogates for Chemical Contaminant Removal During Wastewater Treatment and Reclamation (WERF 04-HHE-1CO). Water Environment Research Foundation, Alexandria, Va.

Ebdon, J.; Muniesa, M.; \& Taylor, H., 2007. The Application of a Recently Isolated Strain of Bacteroides (GB-124) to Identify Human Sources of Faecal Pollution in a Temperate River Catchment. Water Research, 41:16:3683. https://doi. org/10.1016/j.watres.2006.12.020.

Escher, B.I.; Allinson, M.; Altenburger, R.; Bain, P.A.; Balaguer, P.; Busch, W.; Crago, J.; et al., 2013. Benchmarking Organic Micropollutants in Wastewater, Recycled Water and Drinking Water With In Vitro Bioassays. Environmental Science \& Technology, 48:3:1940. https:// doi.org/10.1021/es403899t.

EPHC (Environment Protection and Heritage Council), National Health and Medical Research Council, \& Natural Resource Management Ministerial Council, 2008. Australian Guidelines for Water Recycling: Augmentation of Drinking Water Supplies. EPHC, Canberra, Australia.

Gerba, C.P., 2006 (2nd ed.). Bacteriophage as Pollution Indicators. In The Bacteriophages (R. Calendar, editor). Oxford University Press, New York.

Halliwell, D.; Burris, D.; Deere, D.; Leslie, G.; Jose, R.; \& Blackbeard, J., 2014. Utilization of Hazard Analysis and Critical Control Points Approach for Evaluating Integrity of Treatment Barriers for Reuse (WRRF 03-09). WateReuse Research Foundation, Alexandria, Va.

Havelaar, A.H., 1987. Bacteriophages as Model Organisms in Water Treatment. Microbiological Science, 4:12:362.

Havelaar, A.H.; van Olphen, M.; \& Drost, Y.C., 1993. F-specific RNA Bacteriophages Are Adequate Model Organisms for Enteric Viruses in Freshwater. Applied and Environmental Microbiology, 59:9:2956.

Havelaar, A.H.; Pot-Hogeboom, W.M.; Furuse, K.; Pot, R.; \& Hormann, M.P., 1990. F-specific RNA Bacteriophages and Sensitive Host Strains in Faeces and Wastewater of Human and Animal Origin. Journal of Applied Microbiology, 69:1:30. https://doi.org/10.1111/j.13652672.1990.tb02908.x.

Havelaar, A.H.; Furuse, K.; \& Hogeboom, W.M., 1986. Bacteriophages and Indicator Bacteria in Human and Animal Faeces. Journal of Applied Microbiology, 60:3:255. https://doi.org/10.1111/j.13652672.1986.tb01081.x.

Hsu, F.-C.; Chang, A.; Amante, A.; Shieh, Y-S.C.; Wait, D.; \& Sobsey, M.C., 1996. Distinguishing Human From Animal Fecal Contamination in Water by Typing Male Specific RNA Coliphages. AWWA Water Technology Conference, Boston.

Hsu F-C.; Shieh, Y.-S.C.; van Duin, J.; Beekwilder, M.J.; \& Sobsey, M.D., 1995. 
Genotyping Male-Specific RNA Coliphages by Hybridization With Oligonucleotide Probes. Applied and Environmental Microbiology, 61:11:3960.

IAWPRC Study Group on Health Related Water Microbiology, 1991. Bacteriophages as Model Viruses in Water Quality Control. Water Research, 25:5:529. https://doi.org/10.1016/00431354(91)90126-B.

Jia, A.; Escher, B.I.; Leusch, F.D.L; Tang, J.Y.M.; Prochazka, E.; Dong, B.; Snyder, E.M.; \& Snyder, S.A., 2015. In vitro Bioassays to Evaluate Complex Chemical Mixtures in Recycled Water. Water Research, 80:1. https://doi.org/10.1016/j. watres.2015.05.020.

Jofre, J., 2009. Is the Replication of Somatic Coliphages in Water Environments Significant? Journal of Applied Microbiology, 106:4:1059. https://doi. org/10.1111/j.1365-2672.2008.03957.x.

Jofre, J.; Stewart, J.R.; \& Grabow, W.G., 2011 (1st ed.). Phage Methods. In Microbial Source Tracking: Methods, Applications, and Case Studies (C. Hagedorn, A.R Blanch, \& V.J. Harwood, editors) Springer, New York.

Khan, S., 2013. Drinking Water Through Recycling: The Benefits and Costs of Supplying Direct to the Distribution System. Australian Academy of Technological Sciences and Engineering, Melbourne, Australia.

Love, D. \& Sobsey, M.D., 2007. Simple and Rapid F+ Coliphage Culture, Latex Agglutination, and Typing Assay to Detect and Source Track Fecal Contamination. Applied and Environmental Microbiology, 73:13:4110. https://doi.org/10.1128/AEM.02546-06.

Lucena, F. \& Jofre, J., 2010. Potential Use of Bacteriophages as Indicators of Water Quality and Wastewater Treatment Processes. In Bacteriophages in the Control of Food and Waterborne Pathogens (P.M. Sabour \& M.W. Griffiths, editors). ASM Press, New York. https:// doi.org/10.1128/9781555816629.ch6.

Margiotta-Casaluci, L.; Hannah, R.E.; \& Sumpter, J.P., 2013. Mode of Action of Human Pharmaceuticals in Fish: The Effect of the 5-alpha-reductase Inhibitor Dutasteride, on Reproduction as a Case Study. Aquatic Toxicology, 128-129:113. https://doi.org/10.1016/j.aquatox. 2012.12.003.

Mocé -Llivina, L.; Lucena, F.; \& Jofre, F.J., 2005. Enteroviruses and Bacteriophages in Bathing Waters. Applied and Environmental Microbiology, 71:11:6838. https://doi.org/10.1128/AEM.71.11.68386844.2005.
Mosher, J.; Vartanian, G.; \& Tchobanoglous, G., 2016. Potable Reuse Research Compilation: Synthesis of Findings (WRF Reuse 15-01). Water Environment \& Reuse Foundation, Alexandria, Va.

Myrmel, M.; Berg, E.M.M.; Grinde, B.; \& Rimstad, E., 2006. Enteric Viruses in Inlet and Outlet Samples From Sewage Treatment Plants. Journal of Water and Health, 4:2:197. https://doi.org/10.2166/ wh.2006.0016.

NRC (National Research Council), 2012. Water Reuse: Potential for Expanding the Nation's Water Supply Through Reuse of Municipal Wastewater. The National Academies Press, Washington. https:// doi.org/10.17226/13303

NRC, 2004. Indicators for Waterborne Pathogens. The National Academies Press, Washington. https://doi.org/ 10.17226/11010

NRC, 1982. Quality Criteria for Water Reuse. The National Academies Press, Washington. https://doi.org/10.17226/ 19574

Payment, P. \& Locas, A., 2011. Pathogens in Water: Value and Limits of Correlation With Microbial Indicators. Groundwater, 49:1:4. https://doi.org/10.1111/j.17456584.2010.00710.x

Pepper, I. \& Snyder, S., 2016. Monitoring for Reliability and Process Control of Potable Reuse Applications (WRRF 11-01). WateReuse Research Foundation: Alexandria, Va

Pecson, B.M.; Trussell, R.S.; Pisarenko, A.N.; \& Trussell, R.R., 2015. Achieving Reliability in Potable Reuse: The Four Rs. Journal AWWA, 107:3:48. https://doi. org/10.5942/jawwa.2015.107.0047.

Porter, M.D.; Driskell, J.D.; Kwarta, K.M.; Lipert, R.J.; Neill, J.D.; \& Ridpath, J.F., 2006. Detection of Viruses: Atomic Force Microscopy and Surface Enhanced Raman Spectroscopy. Developments in Biologicals, 126:31.

Rock, C.; Hoppe-Jones, C.; Daniels, K.; Brassill, N.; Hooper, J.; Vandegrift, J.; \& Goldman, J., 2019. Assessment of Techniques to Evaluate Water Quality From Direct and Indirect Potable Facilities. Project 4508. The Water Research Foundation, Denver.

Rock, C.; Snyder, S.; Amador, J.; Hooper, J.; Vandegrift, J.; Osgood, J.; da Silva, A.; \& Bell, K., 2016. Assessment of Techniques to Evaluate and Demonstrate the Safety of Water From Direct Potable Reuse Treatment Facilities, Literature Review. Water Research Foundation, Denver.

Salveson, A.; Mackey, E.; Salveson, M.; \& Flynn, M., 2014. Risk Reduction for Direct Potable Reuse (WRRF 11-10). WateReuse Research Foundation, Alexandria, Va.
Scott, T.M.; Rose, J.B.; Jenkins, T.M.; Farrah, S.R.; \& Lukasik, J., 2002. Microbial Source Tracking: Current Methodology and Future Directions. Applied and Environmental Microbiology, 68:12:5796. https://doi.org/10.1128/AEM.68.12.57965803.2002.

Snyder, S.A., 2014. Emerging Chemical Contaminants: Looking for Greater Harmony. Journal AWWA, 106:8:38. https://doi.org/10.5942/jawwa.2014. 106.0126 .

Snyder, S.A.; Trenholm, R.A.; Snyder, E.M.; Bruce, G.M.; Pleus, R.C.; \& Hemming, J.D.C., 2008. Toxicological Relevance of EDCs and Pharmaceuticals in Drinking Water (WRF 3085). Water Research Foundation, Denver.

Storey, M.V.; van der Gaag, B.; \& Burns, B.P. 2010. Advances in On-Line Drinking Water Quality Monitoring and Early Warning Systems. Water Research, 45:2:741. https://doi.org/10.1016/j. watres.2010.08.049.

SWRCB (State Water Resources Control Board), 2016. Investigation on the Feasibility of Developing Uniform Water Recycling Criteria for Direct Potable Reuse. SWRCB, Sacramento, Calif.

Tartera, C. \& Jofre, J., 1987. Bacteriophages Active Against Bacteroides fragilis in Sewage-Polluted Waters. Applied and Environmental Microbiology, 53:7:1632.

Tartera C.; Lucena, F.; \& Jofre, J., 1989. Human Origin of Bacteroides fragilis Bacteriophages Present in the Environment. Applied and Environmental Microbiology, 55:10:2696.

USEPA (US Environmental Protection Agency), 2017. 2017 Potable Reuse Compendium. EPA/810/R-17/002. USEPA, Washington.

USEPA, 2012. Guidelines for Water Reuse. EPA/600/R-12/618. USEPA, Washington.

USEPA, 2004. Guidelines for Water Reuse. EPA 625/R-04/108. USEPA, Washington.

USEPA, 1992. Guidelines for Water Reuse. EPA 625/R-92/004. USEPA, Washington.

USEPA, 1980. Guidelines for Water Reuse. EPA 600/8-80-036. USEPA, Washington.

USEPA, 1972. EPA Policy Statement on Water Reuse and Water Reuse Background Statement. EPA 832/R-72/102. USEPA, Washington.

Walker, T.; Stanford, B.D.; Khan, S.; Valerdi, R.; Snyder, S.A.; \& Vickers, J., 2016. Critical Control Point Assessment to Quantify Robustness and Reliability of Multiple Treatment Barriers of a DPR Scheme. WRRF-13-03. WateReuse Research Foundation, Alexandria, Va. 
Ware, M.W.; Wymer, L.; Lindguist, H.D.A.; \& Schaefer III, F.W., 2003. Evaluation of an Alternative IMS Dissociation Procedure for Use With Method 1622: Detection of Cryptosporidium in Water. Journal of Microbiological Methods, 55:3:575. https://doi.org/10.1016/j. mimet.2003.06.001.

Welker, M. \& Moore, R.B.E., 2011. Applications of Whole-Cell MatrixAssisted Laser-Desorption/Ionization Time-of-Flight Mass Spectrometry in Systematic Microbiology. Systematic and Applied Microbiology, 34:1:2. https:// doi.org/10.1016/j.syapm.2010.11.013.

WHO (World Health Organization), 2017. Potable Reuse: Guidance for Producing Safe Drinking-Water. WHO, Geneva.

WHO, 2004. Water, Sanitation and Hygiene Links to Health: Facts and Figures. WHO, Geneva.

WHO, 2001. Water Quality: Guidelines, Standards, and Health (L. Fewtrell \& J. Bartram, editors). IWA Publishing, London.

Wolter, A.; Niessner, R.; \& Seidel, M., 2008. Detection of Escherichia coli 0157: H7,
Salmonella typhimurium, and Legionella pneumophila in Water Using a Flow-Through

Chemiluminescence Microarray Readout System. Analytical

Chemistry, 80:15:5854. https://doi. org/10.1021/ac800318b.
Yu, C.; Irudayaraj, J.; Debroy, C.; Schmilovtich, Z.; \& Mizrach, A., 2004. Spectroscopic Differentiation and Quantification of Micro-Organisms in Apple Juice. Journal of Food Science, 69:7:268. https://doi.org/10.1111/j. 1365-2621.2004.tb13627.x.

\section{AWWA RESOURCES}

- AWWA's Focus on Reuse: An Update. Gerling, A., 2019. Journal AWWA, 111:11:78. https://doi.org/10.1002/awwa.1221.

- Planning for Direct Potable Reuse: Operational Aspects of an Integrated Drinking Water System. Stanford, B.D.; Becker, W.C.; Debroux, J.F.; Ishii, S.K.L.; Khan, S.J.; \& Khunjar, W.O., 2016. Journal AWWA, 108:4:48. https://doi. org/10.5942/jawwa.2016.108.0061.

- Sampled Direct Potable Reuse Water Shows Promising Results. SteinleDarling, E.; Sutherland, J.; \& Salveson, A., 2016. Opflow, 42:2:20. https://doi. org/10.5991/OPF.2016.42.0008.

- Achieving Reliability in Potable Reuse: The Four Rs. Pecson, B.M.; Trussell, R.S.; Pisarenko, A.N.; \& Trussell, R.R., 2015. Journal AWWA, 107:3:48. https:// doi.org/10.5942/jawwa.2015.107.0047.

These resources have been supplied by Journal AWWA staff. For information on these and other AWWA resources, visit www.awwa.org. 